\title{
GEL ANTI JERAWAT EKSTRAK DAUN BUTA-BUTA (Excoecaria agallocha L.) DAN PENGUJIAN ANTIBAKTERI Staphylococcus epidermidis
}

\section{ANTI-ACNE GEL FORMULATION OF BUTA-BUTA (Excoecaria agallocha L.) LEAF EXTRACT AND ANTIBACTERIAL TEST AGAINST Staphylococcus epidermidis}

\author{
Ika Olivia Borman ${ }^{1 *}$, Yusriadi $^{1}$, Evi Sulastri $^{1}$ \\ ${ }^{1}$ Jurusan Farmasi, Fakultas MIPA, Universitas Tadulako, Palu, Indonesia.
}

Received 15 Juli 2015, Accepted 20 September 2015

\begin{abstract}
ABSTRAK
Daun Buta-buta (Excoecaria agallocha L.) merupakan jenis tanaman mangrove yang mempunyai aktivitas antibakteri Staphylococcus epidermidis yang merupakan bakteri penyebab jerawat. Penelitian ini bertujuan untuk memformulasikan ekstrak daun buta-buta dengan konsentrasi $12,5 \%$ menjadi gel anti jerawat menggunakan dua pembentuk gel, yaitu HPMC 8\% (Formula 1) dan Karbopol 940 2\% (Formula 2). Pengujian aktivitas antibakteri dengan metode difusi agar menggunakan sumuran. Data stabilitas sediaan selama 28 hari dan aktivitas antibakteri yang diperoleh dianalisis secara statistik menggunakan $t$-student tidak berpasangan dengan derajat kepercayaan $95 \%(\alpha=0,05)$. Hasil evaluasi sediaan gel anti jerawat ekstrak daun buta-buta pada Formula 2 menunjukkan karakteristik yang lebih baik daripada Formula 1, yang meliputi pemeriksaan organoleptik, homogenitas, $\mathrm{pH}$ dan viskositas selama 28 hari. Hasil pengujian antibakteri menunjukkan diameter daya hambat Formula 2 sebesar $11,03 \mathrm{~mm} \pm 0,01$. Hasil analisis statistik menunjukkan terdapat perbedaan bermakna antara Formula 2 dengan kontrol positif (gel klindamisin).
\end{abstract}

Kata Kunci : Ekstrak daun buta-buta, gel anti jerawat, HPMC, Karbopol 940, S.epidermidis

\begin{abstract}
Buta-Buta (Excoecaria agallocha L.) leaf is a type of mangrove plants that has antibacterial activity againtsbacteriacausing acne, Staphylococcus epidermidis,. This study aims to formulate buta-buta leaf extract with the concentration of $12.5 \%$ into anti-acne gel using two gels, namely HPMC 8\% (Formula 1) and Carbopol 940 2\%(Formula 2). Antibacterial activity test was carried out by agar diffusion method using well. The stability and antibacterial activity data during 28 days were analyzed statistically using unpaired $t$-student with a degree of confidence of $95 \%(\alpha=0.05)$. The evaluation results of anti-acne gel form of buta-buta leaf extract in Formula 2 showedbetter characteristics than Formula 1, which include organoleptic examination, homogenity, $\mathrm{pH}$ and viscosity during 28 days. The antibacterial test showed the diameter of inhibition zone of Formula 2 is $11.03 \mathrm{~mm} \pm 0,01$. The statistic analysis showed a significant difference between Formula 2 with a positive control (klindamisin gel).
\end{abstract}

Keywords : Buta-buta leaf extract, anti-acne gel, HPMC, Carbopol 940 , S.epidermidis

*Corresponding author : Ika Olivia Borman, Ikaborman_80@yahoo.com 


\section{PENDAHULUAN}

Jerawat merupakan penyakit kulit yang terjadi akibat peradangan menahun kelenjar polisebasea yang ditandai dengan adanya komedo, papul, pustul, nodus dan kista pada tempat predileksi (Mutschler, 1991), yang disebabkan oleh bakteri Staphylococcus epidermidis (Mitsui, 1997).

Staphylococcus epidermidismemiliki enzim lipase yang dapat menghidrolisis trigliserida di unit sebasea menjadi asam lemak bebas yang dapat menyebabkan terjadinya keratinisasi dan inflamasi yang menimbulkan jerawat (Kligman, 1994).

Buta-buta (Excoecaria agallocha L.) adalah jenis tanaman mangrove dan merupakan obat tradisional yang digunakan oleh masyarakat daerah Desa Margapura Kec. Bolano Lambunu untuk mengobati penyakit bisul dengan penggunaan daunnya yang diserbukkan dan ditempelkan pada bagian yang sakit. Namun hanya beberapa saja yang mengaplikasikannya karena khasiatnya yang belum banyak diketahui. Selain itu tanaman ini dapat mengobati luka berdarah (Verstfegh, 1988). Pada penelitian yang telah dilakukan oleh Masniari Poeloengan dan Andriani (2013) terhadap ekstrak daun buta-buta sebagai antibakteri terhadap bakteri Staphylococcus epidermidis,didapatkan Konsentrasi Hambat Minimal (KHM) sebesar $1 \%$.

Bentuk sediaan gel lebih baik digunakan pada pengobatan jerawat karena sediaan gel dengan pelarut yang polar lebih mudah dibersihkan dari permukaan kulit setelah pemakaian dan tidakmengandung minyak yang dapat meningkatkan keparahan jerawat (Sasanti, dkk,2006).

Bahan pembentuk gel yang biasa digunakan adalah turunan selulosa yaitu HPMC (Hydroxypropyl Methylcellulose) yang dapat menghasilkan gel yang netral, jernih, mempunyai resistensi yang baik terhadap serangan mikroba, dan memberikan kekuatan film yang baik bila mengering pada kulit. Selain itu adalah karbopol 940 yang merupakan pembentuk gel golongan derivat sintetik dapat membentuk gel dengan konsentrasi yang rendah dan menghasilkan viskositas yang tinggi (Rowe, dkk, 2009).

Berdasarkan uraian diatas, maka tujuan dilakukannya penelitian ini adalah untuk memformulasikan gel anti jerawat ekstrak daun buta-buta dan pengujian aktivitasnya terhadap Staphylococcus epidermidis.

\section{METODE PENELITIAN Bahan}

Bahan yang digunakan dalam penelitian ini adalah ekstrak daun buta-buta (Excoecaria agallocha L.), etanol 70\%, HPMC (Hydroxypropyl Methylcellulose), karbopol 940, trietanolamin, propilen glikol, metil paraben, propil paraben, air suling, DMSO (Dimetil sulfoksida), tween $80, \mathrm{NaCl}$ fisiologi, NA (Natrium Agar) dan Clindamycin Poshpate (Medi-Klin $®)$, dan menggunakan bakteri uji Staphylococcus epidermidis.

\section{Determinasi Tanaman}

Determinasi daun buta-buta dilakukan di Pusat Koservasi Tumbuhan Kebun Raya Bogor-LIPI.

\section{Pembuatan ekstrak daun buta-buta (Excoecaria agallocha $\mathbf{L}$.) \\ Serbuk kering daun buta-buta} sebanyak 1,1 g diekstraksi dengan cara maserasi menggunakan pelarut etanol 96\% sebanyak 5 liter selama 3 hari pada suhu ruangan, kemudian dilakukan pengulangan sebanyak 2 kali. Maserat yang diperoleh kemudian diuapkan pelarutnya menggunakan rotary evaporator (Eyela).

\section{Orientasi Pembentuk Gel HPMC} (Hydroxypropyl Methylcellulose)Dan Karbopol 940 Dengan Variasi Konsentrasi

Variasi konsentrasi terhadap pembentuk gel HPMC dapat dilihat pada tabel dibawah ini

Tabel 1. Variasi konsentrasi pembentuk gel HPMC

\begin{tabular}{|c|c|c|c|c|c|c|c|}
\hline \multirow{2}{*}{ No } & \multirow{2}{*}{$\begin{array}{l}\text { Nama } \\
\text { Bahan }\end{array}$} & \multirow{2}{*}{ Kegunaan } & \multicolumn{5}{|c|}{ Konsentrasi Pembentuk Gel HPMC \%b/b } \\
\hline & & & F1 & F2 & F3 & F4 & F5 \\
\hline 1. & HPMC & $\begin{array}{l}\begin{array}{l}\text { Pembentuk } \\
\text { gel }\end{array} \\
\text { g }\end{array}$ & 4 & 5 & 6 & 7 & 8 \\
\hline 2. & $\begin{array}{l}\text { Propilen } \\
\text { glikol }\end{array}$ & Humektan & 10 & 10 & 10 & 10 & 10 \\
\hline 3. & $\begin{array}{l}\text { Metil } \\
\text { paraben }\end{array}$ & Pengawet & 0,2 & 0,2 & 0,2 & 0,2 & 0,2 \\
\hline 4. & $\begin{array}{l}\text { Propil } \\
\text { paraben }\end{array}$ & Pengawet & 0,02 & 0,02 & 0,02 & 0,02 & 0,02 \\
\hline 5. & Akuades & Pembawa & $\begin{array}{c}\text { Hingga } \\
100\end{array}$ & $\begin{array}{c}\text { Hingga } \\
100\end{array}$ & $\begin{array}{c}\text { Hingga } \\
100\end{array}$ & $\begin{array}{c}\text { Hingga } \\
100\end{array}$ & $\begin{array}{c}\text { Hingga } \\
100\end{array}$ \\
\hline
\end{tabular}

Variasi konsentrasi terhadap pembentuk gel karbopol 940 dapat dilihat pada tabel dibawah ini : 
Tabel 2. Variasi konsentrasi basis gel Karbopol 940

\begin{tabular}{|c|c|c|c|c|c|c|c|}
\hline \multirow{2}{*}{ No } & \multirow{2}{*}{$\begin{array}{l}\text { Nama } \\
\text { Bahan }\end{array}$} & \multirow{2}{*}{ Kegunaan } & \multicolumn{5}{|c|}{ Konsentrasi Pembentuk Gel HPMC \%b/b } \\
\hline & & & F1 & F2 & F3 & F4 & F5 \\
\hline 1. & $\begin{array}{l}\text { Karbopol } \\
940\end{array}$ & $\begin{array}{l}\text { Pembentuk } \\
\text { gel }\end{array}$ & 0,5 & 0,75 & 1 & 1,5 & 2 \\
\hline 2. & Trietanolamin & $\begin{array}{l}\text { Pembasa } \\
\text { alkalis }\end{array}$ & 1 & 1 & 1 & 1 & 1 \\
\hline 3. & $\begin{array}{l}\text { Propilen } \\
\text { glikol }\end{array}$ & Humektan & 10 & 10 & 10 & 10 & 10 \\
\hline 4. & $\begin{array}{l}\text { Metil } \\
\text { paraben }\end{array}$ & Pengawet & 0,2 & 0,2 & 0,2 & 0,2 & 0,2 \\
\hline 5. & $\begin{array}{l}\text { Propil } \\
\text { paraben }\end{array}$ & Pengawet & 0,02 & 0,02 & 0,02 & 0,02 & 0,02 \\
\hline 6. & Akuades & Pembawa & $\begin{array}{c}\text { Hingga } \\
100\end{array}$ & $\begin{array}{c}\text { Hingga } \\
100\end{array}$ & $\begin{array}{c}\text { Hingga } \\
100\end{array}$ & $\begin{array}{c}\text { Hingga } \\
100\end{array}$ & $\begin{array}{c}\text { Hingga } \\
100\end{array}$ \\
\hline
\end{tabular}

Formulasi Gel Anti Jerawat Ekstrak Daun

Buta-Buta (Excoecaria AgallochaL.) dengan Variasi Pembentuk Gel HPMC (Hydroxypropyl Methylcellulose) dan Karbopol 940 yang Terpilih

Formulasi gel anti jerawat ekstrak daun buta-buta (Excoecaria agallocha L.) dengan konsentrasi terpilih HPMC dan karbopol 940 dapat dilihat pada tabel dibawah ini :

Tabel 3. Formula Gel

\begin{tabular}{|c|c|c|c|c|}
\hline \multirow{2}{*}{ No } & \multirow{2}{*}{ Nama Bahan } & \multirow{2}{*}{ Kegunaan } & \multicolumn{2}{|c|}{ Konsentrasi \%b/b } \\
\hline & & & F1 & F2 \\
\hline 1. & $\begin{array}{l}\text { Ekstrak daun } \\
\text { buta-buta }\end{array}$ & Zat Aktif & 12,5 & 12,5 \\
\hline 2. & HPMC & $\begin{array}{l}\text { Pembentuk } \\
\text { gel }\end{array}$ & $\begin{array}{c}8 \\
\text { (Konsentrasi } \\
\text { yang } \\
\text { terpilih) }\end{array}$ & - \\
\hline 3. & Karbopol 940 & $\begin{array}{l}\text { Pembentuk } \\
\text { gel }\end{array}$ & - & $\begin{array}{c}2 \\
\text { (Konsentrasi } \\
\text { yang } \\
\text { terpilih) }\end{array}$ \\
\hline 4. & Trietanolamin & $\begin{array}{l}\text { Pembasa } \\
\text { alkalis }\end{array}$ & - & 3,5 \\
\hline 5. & Propilen glikol & Humektan & 10 & 10 \\
\hline 6. & Metil paraben & Pengawet & 0,2 & 0,2 \\
\hline 7. & Propil paraben & Pengawet & 0,02 & 0,02 \\
\hline 8. & Akuades & Pelarut & Hingga 100 & Hingga 100 \\
\hline
\end{tabular}

\section{Cara Pembuatan Gel Ekstrak daun Buta- Buta}

1. Formulasi dengan pembentuk gel HPMC

Pembuatan gel anti jerawat ekstrak daun buta-buta dilakukan dengan mendispersikan HPMC dalam sebagian akuades yang telah dipanaskan pada suhu $80-90^{\circ} \mathrm{C}$, diaduk sampai homogen dan terbentuk massa gel yang jernih, setelah itu ditambahkan ekstrak daun buta-buta dan propil paraben yang telah dilarutkan dengan propilen glikol, diaduk homogen dan ditambahkan metil paraben yang telah dilarutkan dalam sisa akuades lalu diaduk kembali hingga homogen.
2. Formulasi dengan pembentuk gel karbopol 940

Pembuatan gel anti jerawat ekstrak daun buta-buta dilakukan dengan mendispersikan karbopol dengan sebagian akuades yang telah dipanaskan hingga suhu $70^{\circ} \mathrm{C}$, dibiarkan mengembang dan diaduk sampai homogen. Ditambahkan trietanolamin diaduk sampai homogen dan terbentuk massa gel. Kemudian ditambahkan ekstrak daun buta-buta dan propil paraben yang telah dilarutkan dengan propilen glikol, digerus homogen dan ditambahkan metil paraben yang dilarutkan dalam sisa akuades, diaduk hingga homogen.

\section{Pengujian Stabilitas Fisik Gel}

1. Pengamatan Organoleptik sediaan

Pengamatan terhadap bentuk, warna, bau dilakukan secara visual (DepKes RI, 1979).

2. Pengujian homogenitas sediaan

Sejumlah tertentu sediaan dioleskan pada dua kaca atau bahan transparan lain yang cocok, sediaan harus menunjukkan susunan yang baik dan tidak terlihat adanya butiran kasar (DepKes RI, 1979).

3. Pengukuran $\mathrm{pH}$ sediaan Gel

Pemeriksaan $\mathrm{pH}$ dilakukan dengan alat $\mathrm{pH}$ meter. Elektroda dicelupkan dalam wadah tersebut, dibiarkan angka bergerak sampai posisi konstan. Angka yang ditunjukkan oleh $\mathrm{pH}$ meter merupakan nilai pH sediaan tersebut (Voight, 1994 dan Martin, dkk, 1990).

4. Pengukuran viskositas

Sediaan gel dimasukkan ke dalam wadah kemudian diletakkan dalam wadah pada alat viskometer, diatur spindel 6 dengan kecepatan 04 rpm untuk HPMC dan $02 \mathrm{rpm}$ untuk karbopol 940. Alat dioperasikan dengan mencelupkan spindel ke dalam sediaan dan dicatat viskositasnya. (Martin, dkk, 1990).

\section{Penyiapan Bakteri Staphylococcus epidermidis}

1. Pembuatan Medium

Medium NA ditimbang sebanyak $28 \mathrm{~g}$ dan kemudian ditambahkan air $1000 \mathrm{~mL}$, kemudian dipanaskan sampai jernih. 
Setelah itu disterilkan di dalam autoklaf selama 15 menit, pada suhu $121^{\circ} \mathrm{C}$ dan tekanan 2 atm.

\section{Peremajaan Bakteri}

Sejumlah medium dimasukkan ke dalam tabung reaksi kemudian dimiringkan dan dibiarkan hingga setengah memadat dan kemudian digoreskan bakteri. Dimasukkan ke dalam inkubator selama 24 jam.

3. Pembuatan Suspensi Bakteri

$\mathrm{NaCl}$ fisiologi sebanyak $5 \mathrm{~mL}$ dimasukkan ke tabung reaksi yang kemudian digoreskan biakan bakteri 1 ose, setelah itu dihomogenkan dengan vortex.

\section{HASIL DAN PEMBAHASAN}

Hasil Orientasi Basis Gel

Hasil orientasi basis gel dengan HPMC dan karbopol 940 yang meliputi pemeriksaan

\section{Pengujian Antibakteri Terhadap Bakteri Staphylococcus epidermidis}

Pengujian aktivitas gel anti jerawat ekstrak daun buta-buta dengan metode difusi agarmenggunakan sumuran. Pertama-tama dimasukkan medium NA kedalam cawan petri dibiarkan hingga memadat. Kemudian dimasukkan suspensi bakteri $0,1 \mathrm{~mL}$ secara merata dengan menggunakan dispo. Lalu dibuat sumuran kemudian dimasukkan sediaan F2 gel anti jerawat ekstrak daun buta-buta yang telah dilarutkan dalam DMSO dengan konsentrasi $10 \%$ dan telah ditambahkan $1 \mathrm{ml}$ tween 80 untuk menonaktifkan zat pengawet yang terdapat dalam sediaan sebanyak $50 \mu \mathrm{L}$. Diinkubasi pada suhu $37^{\circ} \mathrm{C}$ selama 24 jam. Dilakukan replikasi sebanyak 2 kali. Perlakuaan serupa dilakukan terhadap kontrol negatif dengan menggunakan gel tanpa ekstrak dan untuk kontrol positif digunakan antibiotik gel klindamisin. Setelah itu dinkubasi selama 1x 24 jam dan dihitung daya hambatnya dengan menggunakan jangka sorong.

organoleptik, homogenitas, $\mathrm{pH}$ dan viskositas dapat dilihat pada tabel dibawah ini :

Tabel 4. Hasil Orientasi Basis Gel HPMC

\begin{tabular}{|c|c|c|c|c|c|}
\hline \multirow{2}{*}{ Pemeriksaan } & \multicolumn{5}{|c|}{ Basis HPMC } \\
\hline & F1 & F2 & F3 & F4 & F5 \\
\hline Organoleptik & $\begin{array}{l}\text { Warna } \\
\text { transparan, } \\
\text { bau khas gel, } \\
\text { membentuk } \\
\text { konsistensi } \\
\text { setengah padat }\end{array}$ & $\begin{array}{l}\text { Warna } \\
\text { transparan, } \\
\text { bau khas gel, } \\
\text { membentuk } \\
\text { konsistensi } \\
\text { setengah padat }\end{array}$ & $\begin{array}{l}\text { Warna } \\
\text { transparan, } \\
\text { bau khas gel, } \\
\text { membentuk } \\
\text { konsistensi } \\
\text { setengah padat }\end{array}$ & $\begin{array}{l}\text { Warna } \\
\text { transparan, } \\
\text { bau khas gel, } \\
\text { membentuk } \\
\text { konsistensi } \\
\text { setengah padat }\end{array}$ & $\begin{array}{l}\text { Warna } \\
\text { transparan, } \\
\text { bau khas gel, } \\
\text { membentuk } \\
\text { konsistensi } \\
\text { setengah padat }\end{array}$ \\
\hline Homogenitas & Homogen & Homogen & Homogen & Homogen & Homogen \\
\hline $\mathrm{pH}$ & $5,85 \pm 0,259$ & $5,85 \pm 0,259$ & $5,85 \pm 0,259$ & $5,85 \pm 0,259$ & $5,85 \pm 0,259$ \\
\hline $\begin{array}{l}\text { Viskositas } \\
\text { (cps) }\end{array}$ & $302,2 \pm 0,550$ & $302,2 \pm 0,550$ & $302,2 \pm 0,550$ & $302,2 \pm 0,550$ & $302,2 \pm 0,550$ \\
\hline Keterangan : & $\begin{array}{l}=4 \% \\
=5 \% \\
=6 \%\end{array}$ & $\begin{array}{l}\mathrm{F} 4=7 \% \\
\mathrm{~F} 5=8 \%\end{array}$ & & & \\
\hline
\end{tabular}


Tabel 5. Hasil Orientasi Basis Gel Karbopol 940

\begin{tabular}{|c|c|c|c|c|c|}
\hline \multirow{2}{*}{ Pemeriksaan } & \multicolumn{5}{|c|}{ Basis Karbopol 940} \\
\hline & F1 & F2 & F3 & F4 & $\mathbf{F 5}$ \\
\hline Organoleptik & $\begin{array}{l}\text { Warna } \\
\text { transparan, } \\
\text { bau khas gel, } \\
\text { membentuk } \\
\text { konsistensi } \\
\text { setengah padat }\end{array}$ & $\begin{array}{l}\text { Warna } \\
\text { transparan, } \\
\text { bau khas gel, } \\
\text { membentuk } \\
\text { konsistensi } \\
\text { setengah padat }\end{array}$ & $\begin{array}{l}\text { Warna } \\
\text { transparan, } \\
\text { bau khas gel, } \\
\text { membentuk } \\
\text { konsistensi } \\
\text { setengah padat }\end{array}$ & $\begin{array}{l}\text { Warna } \\
\text { transparan, } \\
\text { bau khas gel, } \\
\text { membentuk } \\
\text { konsistensi } \\
\text { setengah padat }\end{array}$ & $\begin{array}{l}\text { Warna } \\
\text { transparan, } \\
\text { bau khas gel, } \\
\text { membentuk } \\
\text { konsistensi } \\
\text { setengah padat }\end{array}$ \\
\hline Homogenitas & Homogen & Homogen & Homogen & Homogen & Homogen \\
\hline $\mathrm{pH}$ & $7,17 \pm 0,0057$ & $7,17 \pm 0,0057$ & $7,17 \pm 0,0057$ & $7,17 \pm 0,0057$ & $7,17 \pm 0,0057$ \\
\hline $\begin{array}{l}\text { Viskositas } \\
\text { (cps) }\end{array}$ & $29433 \pm 33,50$ & $29433 \pm 33,50$ & $29433 \pm 33,50$ & $29433 \pm 33,50$ & $29433 \pm 33,50$ \\
\hline Keterangan: & $\begin{array}{l}=0,5 \% \\
=0,75 \% \\
=1 \%\end{array}$ & $\begin{array}{l}\mathrm{F} 4=1,5 \% \\
\mathrm{~F} 5=2 \%\end{array}$ & & & \\
\hline
\end{tabular}

\section{Hasil Stabilitas Sediaan Formula 1 dan Formula 2}

Pengamatan stabilitas sediaan gel

Formula 1 dan Formula 2 dilakukan selama 28

hari dengan selang waktu pemeriksaan 7 hari yang meliputi pemeriksaan organoleptik, homogenitas, $\mathrm{pH}$ dan viskositas dapat dilihat pada tabel dibawah ini :

Tabel 6. Hasil Stabilitas Fisik Orientasi Gel HPMC

\begin{tabular}{|c|c|c|c|c|c|c|}
\hline \multirow{2}{*}{ Pemeriksaan } & \multirow{2}{*}{ Sediaan } & \multicolumn{5}{|c|}{ Lama Penyimpanan (Hari) } \\
\hline & & $\mathbf{0}$ & 7 & 14 & 21 & 28 \\
\hline \multirow[t]{4}{*}{ Organoleptik } & $\mathrm{F} 1$ & $\begin{array}{l}\text { Warna hijau } \\
\text { kecoklatan, } \\
\text { bau khas } \\
\text { ekstrak daun } \\
\text { buta-buta, gel } \\
\text { terjadi } \\
\text { sineresis }\end{array}$ & $\begin{array}{l}\text { Warna hijau } \\
\text { kecoklatan, } \\
\text { bau khas } \\
\text { ekstrak daun } \\
\text { buta-buta, gel } \\
\text { terjadi } \\
\text { sineresis }\end{array}$ & $\begin{array}{l}\text { Warna hijau } \\
\text { kecoklatan, } \\
\text { bau khas } \\
\text { ekstrak daun } \\
\text { buta-buta, gel } \\
\text { terjadi } \\
\text { sineresis }\end{array}$ & $\begin{array}{l}\text { Warna hijau } \\
\text { kecoklatan, } \\
\text { bau khas } \\
\text { ekstrak daun } \\
\text { buta-buta, gel } \\
\text { terjadi } \\
\text { sineresis }\end{array}$ & $\begin{array}{l}\text { Warna hijau } \\
\text { kecoklatan, } \\
\text { bau khas } \\
\text { ekstrak daun } \\
\text { buta-buta, gel } \\
\text { terjadi } \\
\text { sineresis }\end{array}$ \\
\hline & $\mathrm{F} 2$ & $\begin{array}{l}\text { Warna coklat } \\
\text { kehijauan, bau }\end{array}$ & $\begin{array}{l}\text { Warna coklat } \\
\text { kehijauan, bau }\end{array}$ & $\begin{array}{l}\text { Warna Warna } \\
\text { coklat }\end{array}$ & $\begin{array}{l}\text { Warna coklat } \\
\text { kehijauan, bau }\end{array}$ & $\begin{array}{l}\text { Warna coklat } \\
\text { kehijauan, bau }\end{array}$ \\
\hline & & $\begin{array}{l}\text { khas ekstrak } \\
\text { daun buta- } \\
\text { buta, } \\
\text { membentuk }\end{array}$ & $\begin{array}{l}\text { khas ekstrak } \\
\text { daun buta- } \\
\text { buta, } \\
\text { membentuk }\end{array}$ & $\begin{array}{l}\text { kehijauan, bau } \\
\text { khas ekstrak } \\
\text { daun buta- } \\
\text { buta, }\end{array}$ & $\begin{array}{l}\text { khas ekstrak } \\
\text { daun buta- } \\
\text { buta, } \\
\text { membentuk }\end{array}$ & $\begin{array}{l}\text { khas ekstrak } \\
\text { daun buta- } \\
\text { buta, } \\
\text { membentuk }\end{array}$ \\
\hline & & $\begin{array}{l}\text { konsistensi } \\
\text { setengah } \\
\text { padat }\end{array}$ & $\begin{array}{l}\text { konsistensi } \\
\text { setengah } \\
\text { padat }\end{array}$ & $\begin{array}{l}\text { membentuk } \\
\text { konsistensi } \\
\text { setengah } \\
\text { padat }\end{array}$ & $\begin{array}{l}\text { konsistensi } \\
\text { setengah } \\
\text { padat }\end{array}$ & $\begin{array}{l}\text { konsistensi } \\
\text { setengah } \\
\text { padat }\end{array}$ \\
\hline \multirow[t]{3}{*}{ Homogenitas } & $\mathrm{F} 1$ & Tidak & Tidak & Tidak & Tidak & Tidak \\
\hline & & Homogen & Homogen & Homogen & Homogen & Homogen \\
\hline & $\mathrm{F} 2$ & Homogen & Homogen & Homogen & Homogen & Homogen \\
\hline \multirow[t]{2}{*}{$\mathrm{pH}$} & $\mathrm{F} 1$ & $5,14 \pm 0,01$ & $5,14 \pm 0,01$ & $5,14 \pm 0,01$ & $5,14 \pm 0,01$ & $5,14 \pm 0,01$ \\
\hline & $\mathrm{F} 2$ & $6,55 \pm 0,011$ & $6,55 \pm 0,011$ & $6,55 \pm 0,011$ & $6,55 \pm 0,011$ & $6,55 \pm 0,011$ \\
\hline \multirow{4}{*}{$\begin{array}{l}\text { Viskositas } \\
\text { (cps) }\end{array}$} & $\mathrm{F} 1$ & 198043 & 198043 & 198043 & 198043 & 198043 \\
\hline & & $\pm 584,494$ & $\pm 584,494$ & $\pm 584,494$ & $\pm 584,494$ & $\pm 584,494$ \\
\hline & $\mathrm{F} 2$ & 412026 & 412026 & 412026 & 412026 & 412026 \\
\hline & & $\pm 25,166$ & $\pm 25,166$ & $\pm 25,166$ & $\pm 25,166$ & $\pm 25,166$ \\
\hline
\end{tabular}

Keterangan: $\quad \mathrm{F} 1=$ Basis HPMC

F2 = Basis Karbopol 940 


\section{Pembahasan}

Penelitian ini menggunakan daun butabuta (Excoecaria agallocha L.) yang dilakukan ekstraksi secara maserasi dengan pelarut etanol selama 3 hari pada suhu ruangan selama 3 kali. Padaproses ekstraksi dilakukan pengadukan agar senyawa-senyawa yang terdapat pada simplisia dapat larut dengan baik. Ekstrak cair yang diperoleh diuapkan pelarutnya dengan menggunakan rotary evaporator pada suhu $50^{\circ} \mathrm{C}$ sampai diperoleh ekstrak kental daun buta-buta.

Sediaan gel pada pengobatan jerawat banyak beredar karena sediaannya tidak mengandung minyak yang dapat meningkatkan keparahan jerawat. Sebagai bahan pembentuk gel, pada formulasi ini digunakan HPMC (Hydroxypropyl Methylcellulose) dan karbopol 940. Mekanisme pembentukan gel oleh HPMC yaitu adanya interaksi antarapolimerpelarutyang menyebabkan jarak antar partikel menjadi kecil dan terbentuk ikatan silang antar molekul yang dapat mengurangi mobilitas pelarut dan selanjutnya terbentuk massa gel, zat aktif terperangkap dalam matriks gel dan pada saat penggunaan dapat dilepaskan. HPMC dapat menghasilkan gel yang netral dan stabil pada pH 3-11 (Rowe, dkk, 2009), mempunyai resistensi yang baik terhadap serangan mikroba, dan memberikan kekuatan film yang baik bila mengering pada kulit (Sasanti, dkk, 2006). Sedangkan karbopol 940 mempunyai struktur senyawa kimia dengan gugus $\mathrm{RCOOH}$ yang bersifat asam. Oleh sebab itu, perlu ditambahkan suatu basa penetral $\left(\mathrm{NaOH}, \quad\right.$ Trietanolamin, $\left.\mathrm{KOH}, \quad \mathrm{NH}_{4} \mathrm{OH}\right)$ sehingga gel mempunyai $\mathrm{pH}$ yang netral dan dapat membentuk viskositas yang baik yang dapat memerangkap zat aktif, namun dapat melepas kembali dengan mudah pada saat penggunaannya. Viskositas gel yang baik yaitu pada $\mathrm{pH}$ 6-11 sedangkan pada $\mathrm{pH}$ kurang dari 3 dan lebih dari 12 viskositas gel akan menurun. (Lachman, dkk, 1994; Rowe, dkk, 2009).

Berdasarkan hasil orientasi terhadap pembentuk gel, dipilih konsentrasi $8 \%$ untuk HPMC dan konsentrasi $2 \%$ untuk karbopol 940sebagai konsentrasi pembentuk gel ekstrak daun buta-buta karena menghasilkan karakteristik yang diinginkan pada pemeriksaan organoleptik, homogenitas, $\mathrm{pH}$, dan viskositas. Pembuatan gel anti jerawat menggunakan bahan lain seperti propilenglikol sebagai humektan untuk mencegah terjadinya pengeringan dalam sediaan dan meningkatkan daya sebar sediaan. Selain itu digunakan kombinasi pengawet yaitu metil paraben dan propil paraben untuk mencegah tumbuhnya mikrorganisme, karena sediaan gel mengandung banyak air yang rentan ditumbuhi mikroorganisme (Lachman, dkk, 1994).

Pemeriksaan organoleptik terhadap sediaan gel anti jerawat selama 28 hari menunjukkan bahwa pada Formula 1 tidak terjadi perubahan bau maupun warna. Tetapi, terjadi perubahan konsistensi bentuk yaitu sineresis pada Formula 1. Sineresis adalah suatu proses yang terjadi akibat adanya kontraksi di dalam massa gel. Cairan yang terjerat akan keluar dan berada di atas permukaan gel. Mekanisme terjadinya kontraksi berhubungan dengan fase relaksasi akibat adanya tekanan elastis pada saat terbentuknya gel. Adanya perubahan pada ketegaran gel akan mengakibatkan jarak antar matriks berubah, sehingga memungkinkan cairan bergerak menuju permukaan (Lieberman, 1989). Faktor yang mempengaruhi sineresis meliputi $\mathrm{pH}$, suhu dan kandungan garam yang terdapat pada gel protein. Pada $\mathrm{pH}$ yang kadar keasamannya tinggi sediaan lebih cepat mengalami sineresis. Pada Formula 1 sineresis disebabkan oleh pengaruh $\mathrm{pH}$ ekstrak daun buta-buta yang bersifat asam yaitu 3,36 sehingga sineresis lebih cepat terjadi yaitu selang waktu 6-7 jam setelah pembuatan gel. Hal tersebut pun mempengaruhi pada homogenitas sediaan Formula 1. Pengaruh lain yang menyebabkan Formula 1 menghasilkan gel yang tidak homogen yaitu karena HPMC dapat membentuk endapan yang tidak larut dengan adanya garam logam (Rowe, dkk, 2009). Dimana daun buta-buta merupakan salah satu jenis tanaman mangrove yang tumbuh di sekitar pantai atau bibir laut yang mempunyai kandungan garam mineral dan logam yang tinggi (Setiawan, dkk, 2002). Sedangkan pada Formula 2 tidak terjadi perubahan bau, warna dan bentuk konsistesinya. Selain itu pemeriksaan homogenitas yang dilakukan selama 28 hari menunjukkan tidak terlihat adanya perubahan perubahan kasar atau partikel-partikel kecil dalam sediaan (homogen). 
Berdasarkan hasil t-student tidak berpasangan pada $\mathrm{pH}$ dan viskositas gel terdapat perbedaan yang nyata antara Formula 1 dan Formula 2 selama penyimpanan 28 hari. Pemeriksaan $\mathrm{pH}$ menunjukkan bahwa kedua Formula memenuhi pH standar kulit yaitu 4,56,5 (Lieberman, 1989). Sedangkan pemeriksaan selama 28 hari pada viskositas menunjukkan bahwa terjadi penurunan yang siginifikan terhadap Formula 1 namun pada Formula 2 tidak terjadi. Perubahan $\mathrm{pH}$ dan viskositas pada Formula 1 dan Formula 2 selama 28 hari dapat dilihat pada grafik 1 dan 2 sebagai berikut :

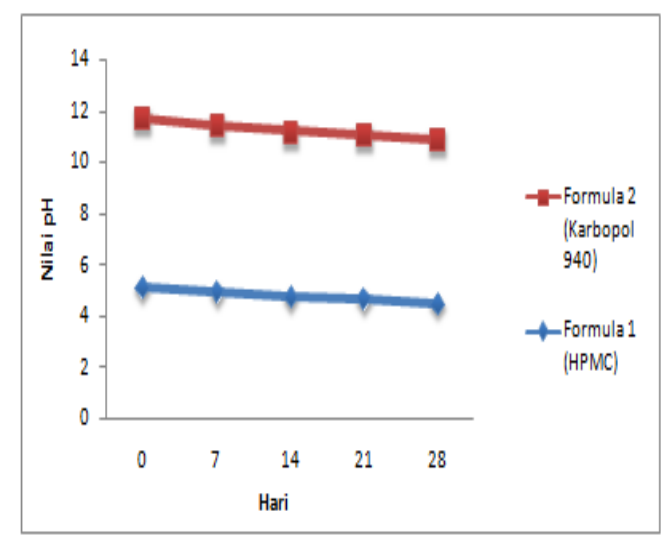

Grafik l. Pengaruh lama penyimpanan terhadap nilai pH pada Formula 1 dan Formula 2

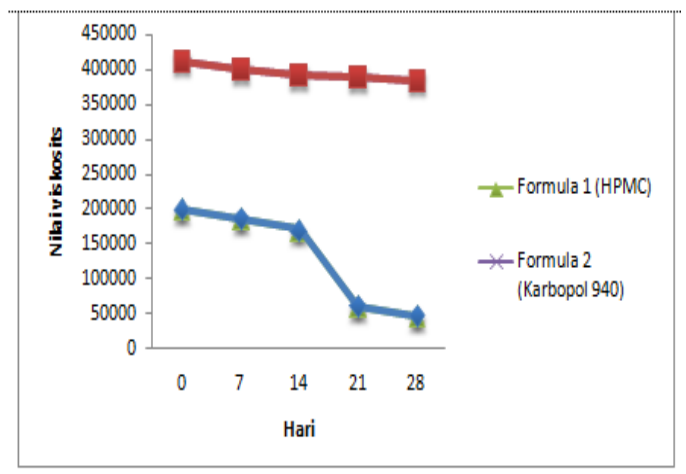

Grafik 2. Pengaruh lama penyimpanan terhadap nilai viskositas pada Formula 1 dan Formula 2

Berdasarkan hasil orientasi ekstrak daun buta-buta dengan konsentrasi 12,5\%, $15 \%, 20 \%$ dan $25 \%$ diperoleh hasil diameter daya hambat yang tidak memiliki perbedaan signifikan. Sehingga pada penelitian ini digunakan konsentrasi ekstrak daun buta-buta $12,5 \%$. Hasil pengujian yang dilakukan pada sediaan gel anti jerawat Formula 2 menunjukkan adanya aktivitas antibakteri dengan terbentuknya diameter daya hambat rata-rata sebesar $11,03 \mathrm{~mm} \pm 0,01$ yang termasuk pada kelompok daya hambat kuat $(10-20 \mathrm{~mm})$ (Davis dan Stout, 1971). Sedangkan pada kontrol positif dengan menggunakan gel klindamisin sulfat mempunyai diameter daya hambat rata-rata sebesar 24,5 $\mathrm{mm} \pm 0,66$ yang termasuk pada kelompok daya hambat sangat kuat (>20 mm) (Davis dan Stout, 1971). Hal ini juga diperkuat dengan penelitian yang dilakukan Masniari Poeloengan dan Andriani (2013) yang melaporkan bahwa penggunaan ekstrak daun buta-buta dengan konsentrasi 12,5\% mempunyai diameter daya hambat rata-rata sebesar 13,33 mm. Berdasarkan hasil t-student tidak berpasangan pada diameter zona hambat bakteri antara kontrol positif dan Formula 2 didapatkan hasil yang berbeda nyata antara kedua sediaan.

Hasil skrining pada penelitian sebelumnya menunjukkan bahwa ekstrak daun buta-buta mengandung beberapa unsur senyawa metabolit sekunder yaitu alkaloid, tanin, saponin, flavanoid dan triterpenoid (Masniari Poeloengan, Andriani, 2013). Sedangkan pada penelitian lain menyebutkan bahwa pada ekstrak daun buta-buta mengandung triterpenoid yaitu lupeol dan senyawa phytol dan squalene (Nurainuna dkk, 2012). Cowan (1999) menyatakan bahwa produk-produk tanaman seperti alkaloid, flavonoid, tanin dan terpenoid merupakan agen antimikroba. Alkaloid dapat menghambat pertumbuhan mikroba karena kemampuannya dalam menginterkalasi dinding sel dan DNA. Flavonoid memiliki aktivitas antibakteri dengan cara membentuk senyawa kompleks terhadap protein extraseluler yang mengganggu integritas membran sel bakteri. Tanin memiliki aktivitas antibakteri berdasarkan kemampuannya dalam membentuk dinding sel dan merusak membran. Sedangkan triterpenoid memiliki aktivitas antibakteri dengan cara merusak membran protein mikroba.

Kesimpulan yang diperoleh dari penelitian ini adalah sediaan gel anti jerawat ekstrak daun buta-buta (Excoecaria agallocha L.) pada Formula2 (Karbopol 940) menunjukkan karakteristik yang lebih baik daripada Formula 1 (HPMC) berdasarkan hasil evaluasi yang meliputi pemeriksaan organoleptik, homogenitas, $\mathrm{pH}$ dan viskositas. yang menunjukkan adanya aktivitas antibakteri Staphylococcus epidermidis dengan diameter daya hambat $11,03 \mathrm{~mm} \pm 0,01$. 


\section{DAFTAR PUSTAKA}

Ansel, H.C. (1989). Pengantar Bentuk Sediaan Farmasi Edisi Keempat (Farida Ibrahim, Penerjemah., UI Presss. Jakarta. 390-391, 607.

Cowan, M.M. (1999). Plant Products as Antimicrobial Agents. Clinical Microbiology Reviews. 12. 564-582.

Departemen Kesehatan Republik Indonesia. (1979). Farmakope Indonesia, Edisi Ketiga. Departemen Kesehatan Republik Indonesia. Jakarta. 96, 756.

Kligman, F. (1994). Identification of Salmonella typhii. Journal of Microbiology. 288-300.

Lachman, L., Herbert, A., Lieberman., Joseph, L., Kanig. (1994). Teori dan Praktek Farmasi Industri. UI Press. Jakarta. 1092, 1119-1120, 1110, 1128.

Lieberman., Rieger., \& Bsnker. (1989). Pharmaceutical Dosage Form : Disperse System. Vol ke-2. Dekker Inc. New York. 490-492, 495-508.

Martin, A., Swarbick, J., Cammarata, A. (1990). Dasar-Dasar Farmasi Fisik dalam Ilmu Farmasi, Jilid 1. Penerbit Univeritas Indonesia. Jakarta. 25.

Poeloengan M. \& Andriani. (2013). Kandungan Senyawa Aktif dan Daya Antibakteri Daun Sambung Darah (Active Compounds And Antibacterial Activity of Excoecaria agallocha), Laboratorium Bakteriologi : Balai Besar Penelitian Veteriner, Vol. 14, No. 2. Bogor. 145-152.
Mitsui, T. (1997). New Cosmetic Science. Shiseido Co Ltd. Tokyo. 28-31.

Nurainuna, H., Basyunib, M., Putric, L.A.P. (2012). Karakterisasi Senyawa Isoprenoid Sebagai Produk Alami Pada Mangrove Sejati Minor Non Sekresi Excoecaria agallocha L., Di Hutan Mangrove Sumatera Utara, Program Studi Agroekoteknologi, Universitas Sumatera Utara. Sumatera Utara.

Rowe, R.C., Paul, J.S., \& Marian, E.Q. (2009). Handbook Of Pharmaceutical. Exipients Sixth Edition. Pharmaceutical Press. London. 110113, 326-329, 441-444, 592-593, 596598. 754-755.

Sasanti, T.J., Wibowo, M.S., Fidrianny, I., \& Caroline, S. (2006). Formulasi Gel Ekstrak Air Teh Hijau dan Penentuan Aktivitas Antibakterinya terhadap Propionibacteria acnes (Skripsi). Sekolah Farmasi-ITB, Bandung, 8-11.

Setiawan, D.A., dkk. (2002). Biodervisitas Genetik, Spesies, dan Eksosistem Mangrove Di Jawa, Kelompok Kerja Biodiversitas. Jurusan Biologi Fakultas Matematika dan Ilmu Pengetahuan Alam. Universitas Sebelas Maret. Surakarta, 22-23.

Verstfegh, J.K. (1988). Petunjuk lengkap mengenai tanaman-tanaman di Indonesia dan khasiatnya sebagai obatobatan tradisional. Balitbangkes. Depkes RI. Jakarta. 167.

Voight, R. (1994). Buku Pelajaran Tekhnologi Farmasi. Gajah Mada University Press. Yogyakarta. 341. 